\title{
Hieracia balcanica VIII. Hieracium nigrescens subsp. brachytrichellum (Asteraceae), a new taxon in the Balkan flora
}

\author{
Zbigniew SzELĄG \\ Institute of Botany, Jagiellonian University, Kopernika 31, 31-501 Kraków, Poland; e-mail: azszelag@wp.pl
}

\begin{abstract}
Hieracium nigrescens subsp. brachytrichellum Zahn, known to date only from the Southern Carpathians, was discovered in the Vranica Mountains in Bosnia. This is the first station of $H$. nigrescens s.l., an arctic-alpine species of $H$. sect. Alpina (Griseb.) Gremli, on the Balkan Peninsula. A map of general distribution of H. nigrescens s.l. and illustration of the specimens collected in Bosnia are given. The likely origin of the Balkan population is briefly discussed.
\end{abstract}

Key words: Hieracium sect. Alpina; Balkans; distribution map; Pleistocene migration; relict population; Vranica Mts

\section{Introduction}

According to Stevanović et al. (2009), 77 arctic-alpine species of vascular plants occur on the Balkan Peninsula. From a phytogeographical point of view these species belong to the Holarctic element and the ArcticAlpic sub-element (Zając \& Zając 2009). The term 'alpic' is used following Meusel in Horvat et al. (1974) for the plants which occur in the Alps, while the term 'alpine' is used to mean plants which grow in the alpine zone of the high mountain. Historically, the arcticalpine species in the Balkans are considered Pleistocene relics, which have migrated repeatedly to southern Europe during consecutive glaciations (Lang 1994). The distribution of the arctic-alpine, mostly silicophilous, species on the Balkan Peninsula is disjunctive and is limited to a few highest massifs (Horvat 1953; Horvat et al. 1974). The highest concentration of these species (63) occurs in the Dinaric Mountains (Stevanović et al. 2009). The only representative of the Arctic-Alpic sub-element from the genus Hieracium L. in the Balkan flora hitherto known is $H$. alpinum $\mathrm{L}$., discovered in the Vranica Mountains in Bosnia by Horvat \& Pawłowski (1939).

\section{Material and methods}

In August 2010 I was carrying out a field research in Bosnia and Herzegovina, visiting among other sites the Vranica Mountains in the Dinaric Mountains. My objective was to re-find $H$. alpinum Horvat \& Pawłowski's (1939) as well as several other taxa of Hieracium that were discovered there and described by Pawlowski (1963) from this mountain range. Taxonomic treatment of Hieracium follows Zahn (1938). Pollen grains were examined with a light microscope. All collected plants are stored at my Herbarium Hieraciorum.
A map of distribution of $H$. nigrescens s.l. sensu Zahn (1938) is based on literature data, mostly on monographs by Zahn (1921-1923, 1938), my own research in the Carpathians, Sudetes and Alps as well as on revised specimens from many European herbaria.

\section{Results}

On 3 August 2010, during search on Mt. Nadkrstac (2112 m a.s.l., $43^{\circ} 57^{\prime} 26^{\prime \prime} \mathrm{N} 17^{\circ} 44^{\prime} 24^{\prime \prime} \mathrm{E}$ ), the highest peak of the mountain range, I found Hieracium nigrescens subsp. brachytrichellum Zahn (Fig. 1). No representative of the arctic-alpine $H$. nigrescens agg. [H. nigrescens s.l. sensu Zahn (1938)] has not yet been found on the Balkan Peninsula. It grew in grassy places in Pinus mugo communities, a few dozen metres NW of the summit, at $2100 \mathrm{~m}$ a.s.l. Altogether I found about 40 flowering individuals in several patches. Hieracium nigrescens subsp. brachytrichellum grew in association with Deschampsia flexuosa (L.) Trin., Geum montanum L., Gnaphalium norvegicum Gunn., Ligusticum mutellina (L.) Crantz, Phyteuma confusum Kern., Potentilla aurea L., Pulsatilla alpina L. and Ranunculus crenatus Waldst. \& Kit. Nearby on rocky places on the summit were also Achillea lingulata Waldst. \& Kit., Agrostis rupestris All., Arnica montana L., Carex curvula All., Empetrum hermaphroditum Hagerup, Festuca halleri All., Hieracium amphigenum Briq., Jasione orbiculata Griseb., Juncus trifidus L., Sedum alpestre Vill., Senecio carpaticus Herb., Tanacetum alpinum SchultzBip., Vaccinium gaultheroides Bigelow and Hieracium alpinum L., which recently was found to be triploid in the Vranica Mountains (Mráz et al. 2009; Ilnicki \& Szeląg 2011).

All collected and examined Hieracium nigrescens subsp. brachytrichellum plants produce irregular pollen grains of varying size. 


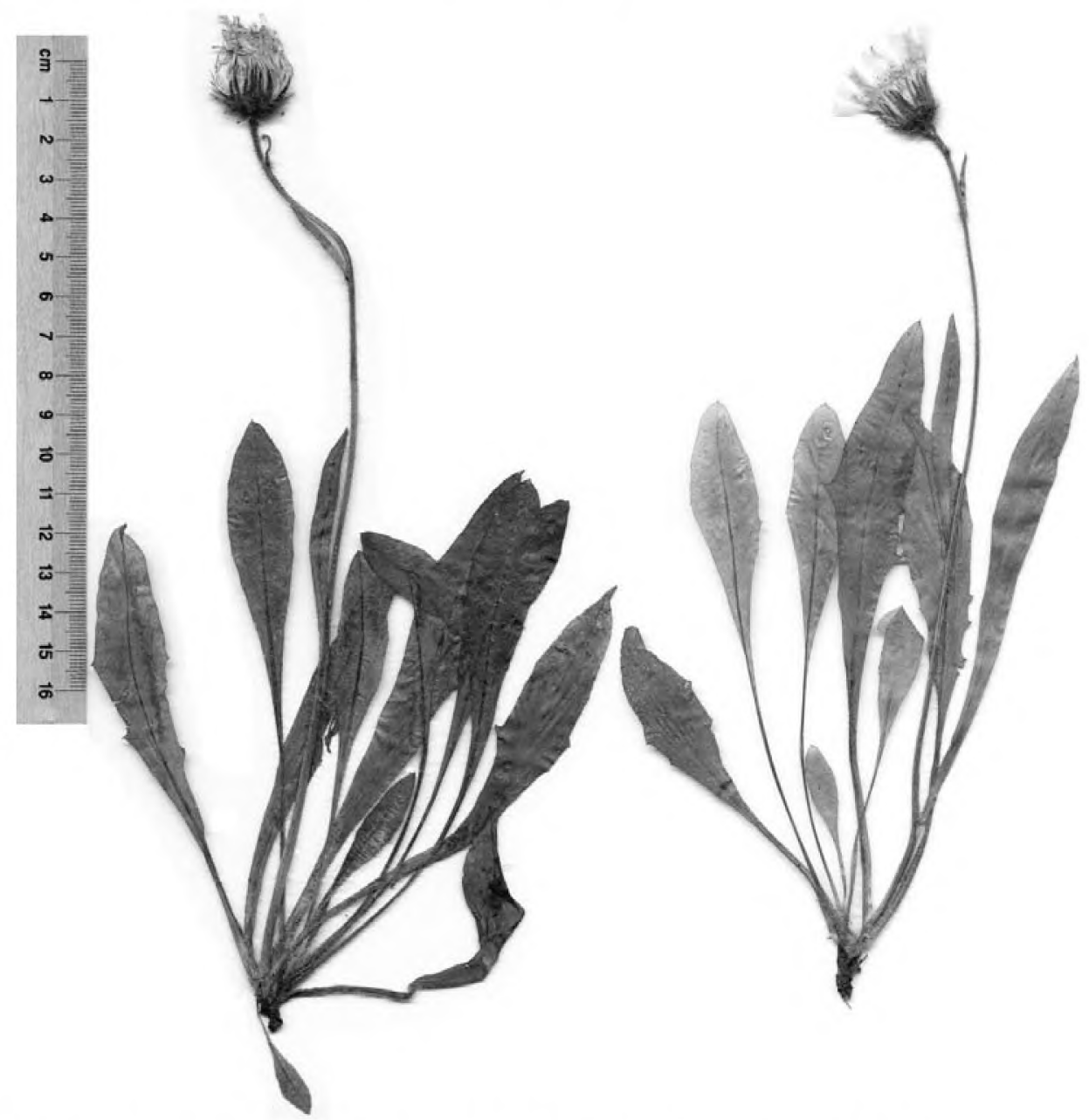

Fig. 1. Specimens of Hieracium nigrescens subsp. brachytrichellum Zahn from the Vranica Mountains.

Hieracium nigrescens s. l. sensu Zahn (1938) is one of many species of the genus Hieracium for which no reliable distribution map is available. It is not clear if the Hultén and Fries' (1986) map for 'Nigriscentia group' shows in fact only $H$. nigrescens s.l. sensu Zahn (1938) or comprises also taxa of $H$. atratum s.l. Even if it does contain only $H$. nigrescens s.l., it is not complete and for the Central European part of the range is imprecise. I present here an updated map of distribution of H. nigrescens s.l. (sensu Zahn 1938) that includes the newly discovered Balkan location (Fig. 2). The northern part of the range, comprising Greenland, Iceland, Scandinavia and NW Russia, generally agrees with that of Hultén and Fries (1986). The remaining part, comprising the British Isles, Urals, Alps, Sudetes, Harz and Carpathians was outlined taking into consideration the modern regional elaborations (Chrtek 1995, 1997, 2004; Chrtek \& Mráz 2007; Nyárády 1965; Sell et al. 1995; Tennant \& Rich 2002, 2008; Tupitzina 2004).

\section{Discussion}

Hieracium nigrescens s.l. belongs to $H$. sect. Alpina (Griseb.) Gremli and comprises taxa of presumably hybrid origin, of morphological formula $H$. alpinum $>$ H. murorum (Zahn 1921-1923). The plants found in the Vranica Mountains I regard as belonging to H. nigrescens subsp. brachytrichellum. This taxon has been known before from the Retezat Mountains on the western-most part of the Southern Carpathians (Zahn 1938; Nyárády 1965). The plants from the Vranica Mountains are also very similar to $H$. nigrescens subsp. gymnogeniforme Zahn that occurs throughout the whole Southern and Eastern Carpathians, but have dark styles in contrast to $H$. nigrescens subsp. brachytrichellum which has yellow styles. Both Zahn (1938) and Chrtek $(1995,1997)$ regard style colour as being taxonomically important.

Within Hieracium nigrescens s.l., Zahn (19211923, 1938) considered about 150 taxa at subspecies rank, of which more than 100 occurred in northern Europe. Such a multitude of taxa seems to exhaust all possible morphological combinations and suggests that taxonomic status of the Vranica individuals should be assessed as part of a thorough revision of $H$. nigrescens s.l. at least in the Alps and Carpathians. To date only a small part of Sudetic, Western Carpathian and British Isles' $H$. nigrescens s.l. taxa have been revised taxonomically (Chrtek 1995, 1997; Chrtek \& Mráz 2007; Tennant \& Rich 2008).

From a phytogeographical point of view, the Varnica Mountains are an exceptional place in the western 


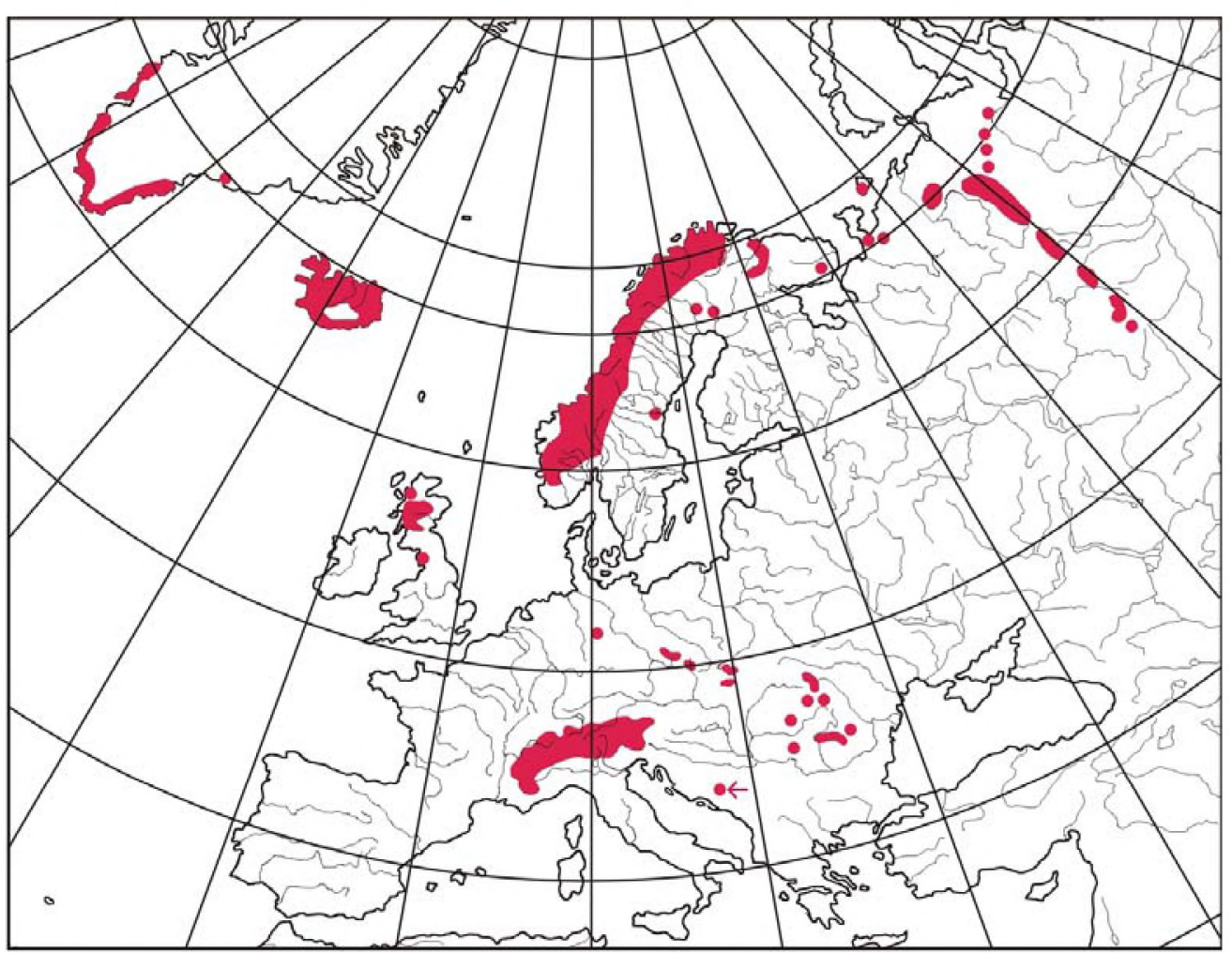

Fig. 2. General distribution of Hieracium nigrescens s.l., a new locality marked with an arrow.

part of the Balkan Peninsula. The flora and vegetation display a considerable resemblance to those of the Carpathians (Redžić 2007; Stefanović et al. 2009). Of the species occurring on the Vranica Mountains whose the centre of range is to be found in the Carpathians, the most spectacular example is Leucanthemum waldsteinii (Schultz-Bip.) Pouzar. This Carpathian subendemic has its only non-Carpathian station in the Vranica Mountains discovered also by Horvat and Pawłowski (1939). Out of the whole of the Dinaric Mountains, only on the Vranica Mountains does Carex curvula All. grow, forming an association Phyteumo confusae-Caricetum curvulae (Redžić 2007) having a very similar species composition to Primulo minimaeCaricetum curvulae from the Southern Carpathians (Coldea 1991). The latest phylogeographic studies on Carex curvula revealed a genetic uniformity of the whole eastern (i.e. Carpathian-Balkan) part of the species range, which supported the hypothesis of a long-term separation of the eastern (Carpathians and Balkans) and western (Alps and Pyrenees) lineages of this species (Puşcaş et al. 2008).

The Vranica Mountains are an isolated area where arctic-alpine vascular plants and bryophytes occur that migrated from the Alps and Carpathians south-eastwards to the Prokletije Mountains on the southernmost part of the Dinaric Mountains and to the Scardo-Pindic massifs during the Pleistocene (Horvat 1953, 1954; Martinčič 2006). In my opinion, this scenario is also valid for Hieracium nigrescens subsp. brachytrichellum, whose population on the Vranica Mountains is a remnant of the Pleistocene migration wave of mountain flora from the Southern Carpathians. It is hoped to study of the genetic relationships between H. nigrescens subsp. brachytrichellum from the Vranica Mountains and Carpathians in the near future.

\section{Acknowledgements}

I am grateful to Dr. Tim Rich (Cardiff) for valuable remarks on the manuscript and English correction, to Dr. Jindřich Chrtek (Průhonice) for helpful discussion, and to Dr. Patrik Mráz for critical comments and helpful suggestions on the manuscript. This study was supported by the Polish Ministry of Sciences and Higher Education, grant no. NN303089734.

\section{References}

Chrtek J. 1995. Notes on Hieracium alpinum and Hieracium nigrescens groups (section Alpina Fries) in the Eastern Sudeten (Mt. Králický Sněžník, the Hrubý Jeseník Mts.). Preslia 67: 97-106.

Chrtek J. 1997. Hieracium decipientiforme (the H. nigrescens group) - an interesting species of the Ukrainian Carpathians. Preslia 69: 121-128.

Chrtek J. 2004. Hieracium L., pp. 540-701. In: Slavík B., Stěpánková J. \& Stěpánek J. (eds), Květena Ceské Republiky vol. 7. Academia, Praha.

Chrtek J. \& Mráz P. 2007. Taxonomic revision of Hieracium nigrescens agg. in the Western Carpathians. Preslia 79: 45-62.

Coldea G. 1991. Prodrome des associations végétales des Carpates du Sud-Est (Carpates Roumaines). Documents Phytosociologiques Nouv. Sér. 13: 315-539.

Horvat I. 1953. Prilog poznavanju raširenja nekih planinskih biljaka u jugoistočnoj Evropi. Godišnj. Biol. Inst. u Sarajevu 5: 199-217. 
Horvat I. 1954. Pflanzengeographische Gliederung Südosteuropas. Vegetatio Acta Geobot. 5/6: 434-447.

Horvat I., Glavač V. \& Ellenberg H. 1974. Vegetation Südosteuropas. Gustav Fischer Verlag, Stuttgart, $768 \mathrm{pp}$.

Horvat I. \& Pawłowski B. 1939. Istraživanje vegetacije planine Vranice. Ljetopis Jugoslav. Akad. Znam. Umj. Zagreb 51: $149-152$.

Hultén E. \& Fries M. 1986. Atlas of north European vascular plants north of the Tropic of Cancer. Koeltz Scientific Books, Königstein, $1149 \mathrm{pp}$.

Ilnicki T. \& Szeląg Z. 2011. Chromosome numbers in Hieracium and Pilosella (Asteraceae) from Central and Southeastern Europe. Acta Biol. Cracoviensia Ser. Bot. 53: 102-110.

Lang G. 1994. Quartäre Vegetationsgeschichte Europas. Methoden und Ergebnisse. Gustav Fischer Verlag, Jena, Stuttgart, New York, $462 \mathrm{pp}$.

Martinčic A. 2006. Moss flora of the Prokletije Mountains (Serbia and Montenegro). Hacquetia 5: 113-130.

Mráz P., Chrtek J. \& Šingliarová B. 2009. Geographical parthenogenesis, genome size variation and pollen production in the arctic-alpine species Hieracium alpinum. Bot. Helv. 119: 4151.

Nyárády E.I. 1965. Hieracium L., pp. 214-746. In: Nyárády E.I. (ed.), Flora Republicii Populare Romîne, vol. 10. Editura Academiei Republicii Populare Romîne, București.

Pawłowski B. 1963. Hieracia balcanica nova vel minus cognita. Acta Soc. Bot. Pol. 32: 473-491.

Puşcaş M., Choler P., Tribsch A., Gielly L., Rioux D., Gaudeul M. \& Taberlet P. 2008. Post-glacial history of the dominant alpine sedge Carex curvula in the European Alpine System inferred from nuclear and chloroplast markers. Mol. Ecol. 17: $2417-2429$.
Redžić S. 2007. Syntaxonomic diversity as an indicator of ecological diversity - case study Vranica Mts in the Central Bosnia. Biologia 62: 173-184.

Sell P.D., West C. \& Tennant D.J. 1995. Eleven new British species of Hieracium L. section Alpina (Fries) F. N. Williams. Watsonia 20: 351-365.

Stevanović V., Vukojičić S., Sinžar-Sekulić J., Lazarević M., Tomović G. \& Tan K. 2009. Distribution and diversity of ArcticAlpine species in the Balkans. Plant Syst. Evol. 283: 219-235.

Tennant D.J. \& Rich T.C.G. 2002. Distribution maps and IUCN threat categories for Hieracium section Alpina (Asteraceae) in Britain. Edinb. J. Bot. 59: 351-372.

Tennant D.J. \& Rich T.C.G. 2008. British alpine hawkweeds. A monograph of British Hieracium section Alpina. Botanical Society of the British Isles, London, $234 \mathrm{pp}$.

Tupitzina N.N. 2004. The hawkweeds of Sibeira. Nauka, Novosibirsk, $210 \mathrm{pp}$.

Zahn K.H. 1921-1923. Hieracium L., pp. 1-1705. In: Engler A. (ed.), Das Pflanzenreich Regni Vegetabilis Conspectus IV/280. Wilhelm Engelmann, Leipzig.

Zahn K.H. 1938. Hieracium L., pp. 1-708. In: Graebner P. fil. (ed.), Synopsis der mitteleuropäischen Flora 12(3). Borntraeger, Berlin.

Zając M. \& Zajac A. 2009. The geographical elements of native flora of Poland. Laboratory of Computer Chorology, Institute of Botany, Jagiellonian University, Kraków, 94 pp.

Received June 26, 2011

Accepted September 29, 2011 